Portland State University

PDXScholar

$5-12-1977$

\title{
Behavioral Temperature Regulation in the Turtle Pseudemys scripta elegans
}

Michael H. Johnston

Portland State University

Follow this and additional works at: https://pdxscholar.library.pdx.edu/open_access_etds

Part of the Biology Commons, and the Other Animal Sciences Commons Let us know how access to this document benefits you.

\section{Recommended Citation}

Johnston, Michael H., "Behavioral Temperature Regulation in the Turtle Pseudemys scripta elegans" (1977). Dissertations and Theses. Paper 2443.

https://doi.org/10.15760/etd.2440

This Thesis is brought to you for free and open access. It has been accepted for inclusion in Dissertations and Theses by an authorized administrator of PDXScholar. Please contact us if we can make this document more accessible: pdxscholar@pdx.edu. 
AN ABSTRACT OF THE THESIS OF Michael H. Johnston for the Master of Science in Biology presented 12 May 1977.

Title: Behavioral Temperature Regulation in the Turtle Pseudemys scripta elegans

APPROVED BY MEMBERS OF THE THESIS COMMITTEE:

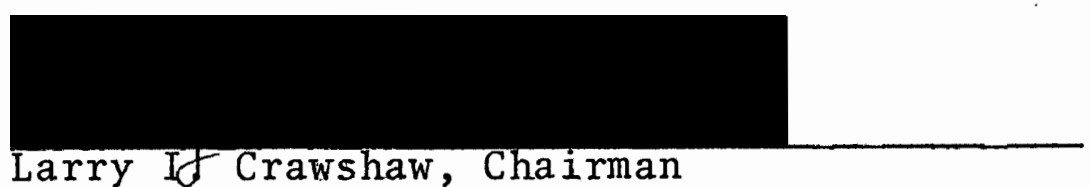

Larry If Crawshaw, Chairman
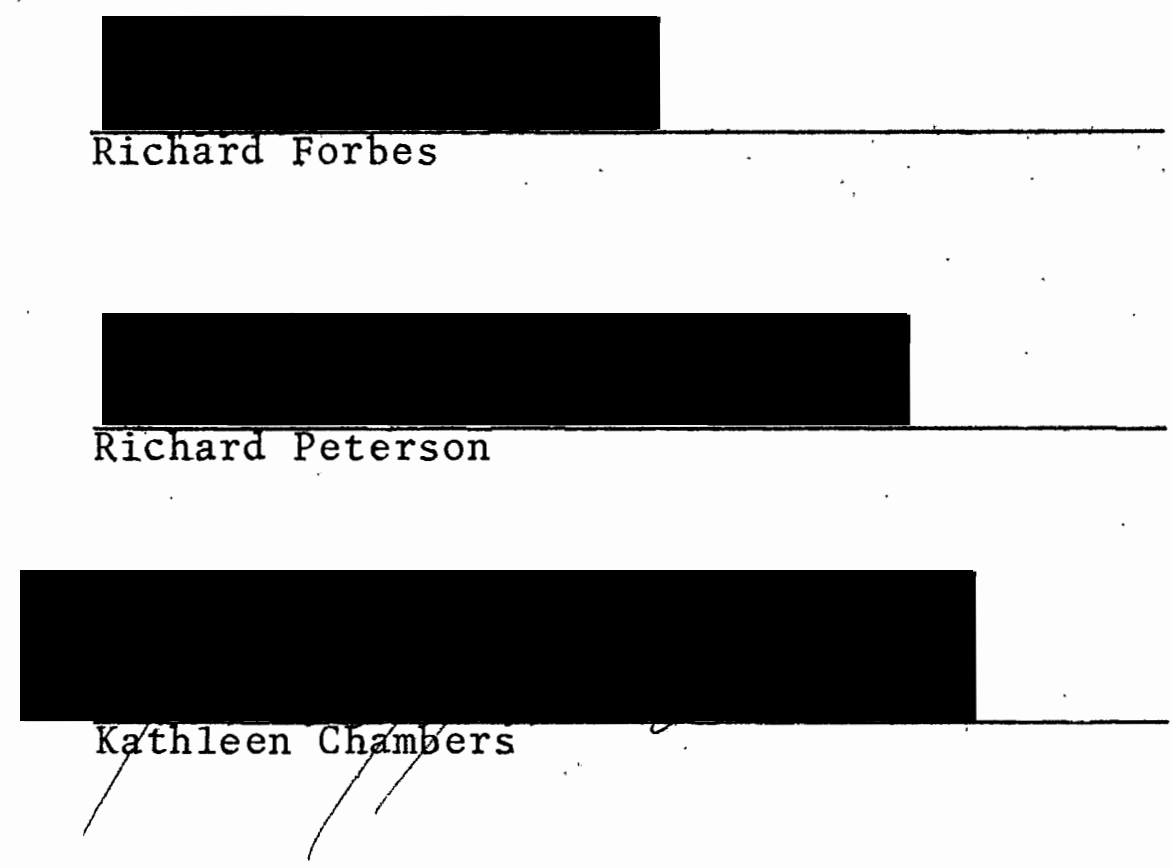

A group of red-eared turtles (Pseudemys seripta elegans) was acclimated to $18-20^{\circ} \mathrm{C}$ and an artificial photoperiod for 21 days. The animals were then individually 
placed in a thermal gradient and their selected temperatures were continuously recorded for. 24 hours. A second group of turtles was acclimatized to $7.5-11.0^{\circ} \mathrm{C}$ and natural photoperiods for 28 days, and subsequently tested in the same manner as the first group. Lastly, the turtles in the first group, after being acclimated to $3.0^{\circ} \mathrm{C}$ and the previous artificial photoperiod for 14 days, were retested in the gradient.

Initial responses of a11 groups were characterized by a rapid selection of warm temperatures. Within 14 hours of initial gradient exposure the mean selected temperature of each group was between 31 and $33^{\circ} \mathrm{C}$. The final thermal preferendum of $P$. s. elegans is, therefore, probably between 31 and $33^{\circ} \mathrm{C}$.

The final thermal preferendum of $P . s$. elegans is related to a variety of biological factors. However, in the light of present knowledge about the effects of temperature on $\mathrm{pH}$ and ventilation in this species, the results of this study suggest that attainment of the final thermal preferendum may be related to acid-base parameters. 
BEHAVIORAL TEMPERATURE REGULATION IN THE TURTLE Pseudemys scripta elegans

$$
\text { by }
$$

\title{
MICHAEL H. JOHNSTON
}

\begin{abstract}
A thesis submitted in partial fulfillment of the requirements for the degree of
\end{abstract}

\section{MASTER OF SCIENCE in BIOLOGY}

\author{
Portland State University \\ 1977
}


TO THE OFFICE OF GRADUATE STUDIES AND RESEARCH:

The members of the Committee approve the thesis of Michae1 H. Johnston presented 12 May 1977.
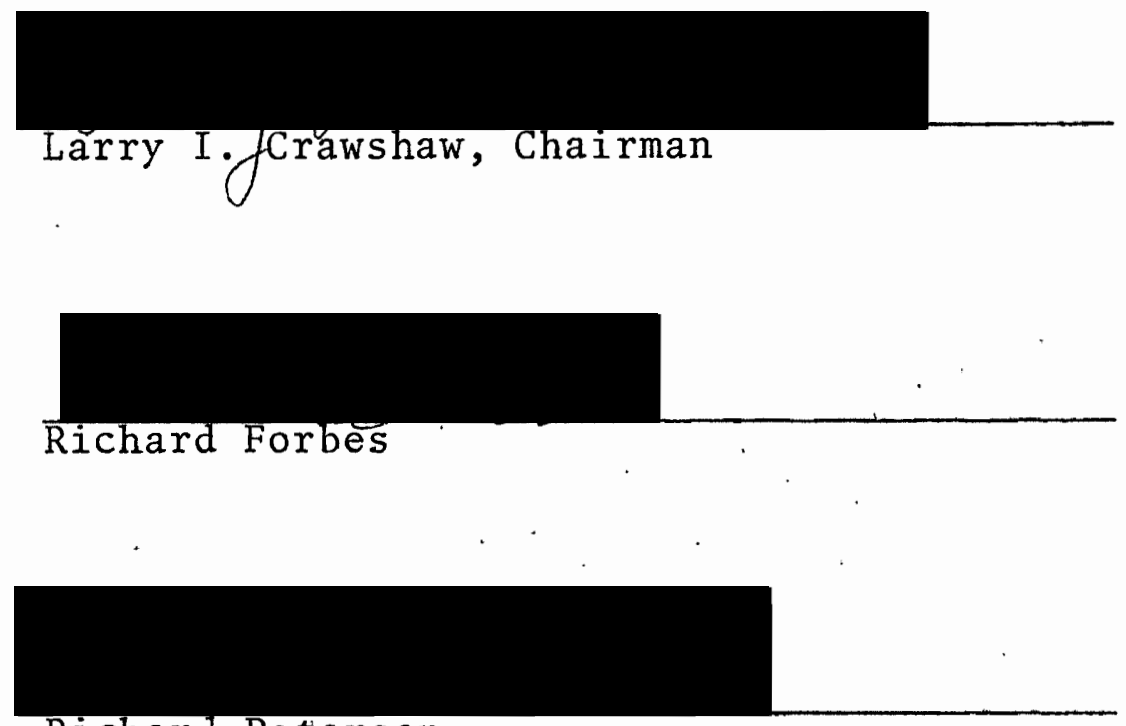

Richard Peterson

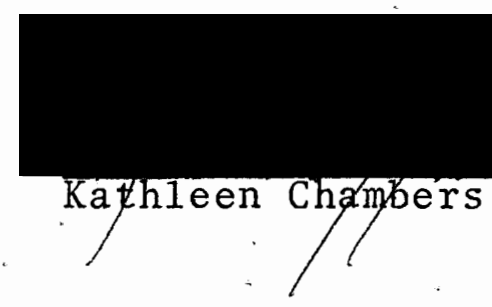

APPROVED :

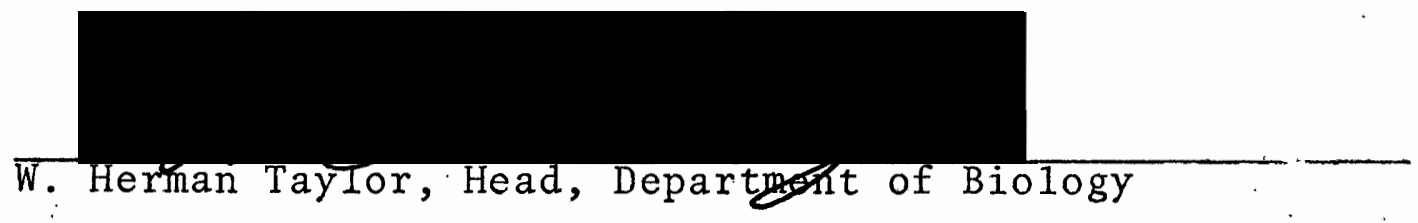

Stanley E. Rauch, Dean, Graduate Studies and Research. 


\section{ACKNOWLEDGEMENTS}

Sincere gratitude is extended to Dr. Larry I. Crawshaw for his patience, objectivity and critical review of the thesis manuscript; to Paul Paquet for his kind support, and review of the original draft; to Dr. Richard Forbes, whose 12 years of untiring guidance, encouragement and frièndship have directed my energy and success; to Mrs. Lee Hawọth of the Federal Aviation Administration, without whose total commitment this program would not have succeeded; and finally to President John Leyden and all members of the Professional Air Traffic Controllers Organization, without whose support this program would not have been possible.

This study was supported by NSF Grant \#PCM 76-09658, and by Public Law 92-297 (92nd Congress). 
TABLE OF CONTENTS

PAGE

ACKNOWLEDGEMENTS $\ldots \ldots \ldots \ldots \ldots \ldots \ldots \ldots \ldots \ldots \ldots \ldots \ldots \ldots$

LIST OF TABLES $\ldots \ldots \ldots \ldots \ldots \ldots \ldots \ldots \ldots \ldots \ldots \ldots \ldots \ldots$

LIST OF FIGURES $\ldots \ldots \ldots \ldots \ldots \ldots \ldots \ldots \ldots \ldots \ldots \ldots \ldots$

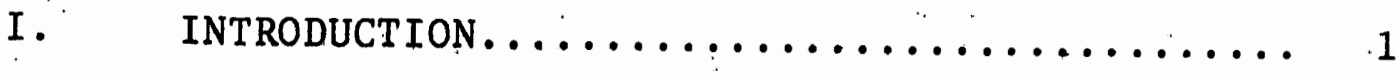

II. MATERIALS AND METHODS.............. 5

III. RESULTS.......................... 12

IV. DISCUSSION........................... 24

Acclimation....................... 24

Photoperiod, Activity and Thermotaxis...... 24

Homeostasis as a Function of Adaptative

Behavior...................... 25

y. CONCLUSION...................... 28

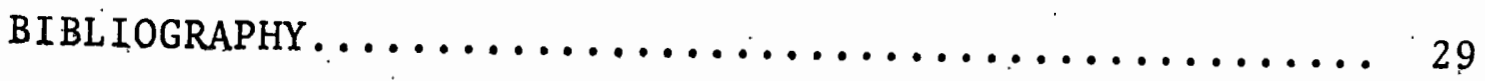




\section{LIST OF TABLES}

TABLE

PAGE

I Physical Characteristics of Experimental Subjects........................ 6

II Mean Selected Temperatures of Individuals

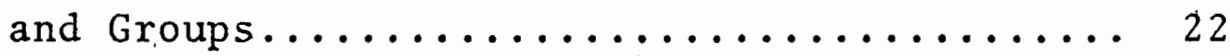




\section{LIST OF FIGURES}

FI GURE

PAGE

1 Temperature gradient apparatus............. 8

2 Selected temperature as a function of time

for the 6 turtles acclimated to $18-20^{\circ} \mathrm{C} \ldots \ldots 13$

3 Selected temperature as a function of time

for the 5 turtles acclimatized to natural

photoperiod and $7.5-11.0^{\circ} \mathrm{C} \ldots \ldots \ldots \ldots \ldots$

4 Selected temperature as a function of time

in the 6 turtles acclimated to $3^{\circ} \mathrm{C} \ldots \ldots . . . .15$

5 Mean selected temperature as a function of

time for Groups I, II and III............ 16

6 Mean activity as a function of time in the

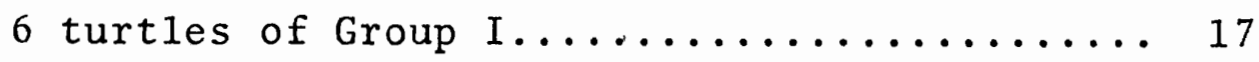

7 Mean activity as a function of time in the

5 turtles of Group II.................. 18

8 Mean activity as a function of time in the

6 turtles of Group III................. 19

9 Mean thermal range as a function of time in

the turtles of Groups I, II, and III....... 20 


\section{INTRODUCTION}

Recognition that all but slight changes in body temperature may result in large deviation from normal physiological status is of fundamental importance in understanding homeostasis of systemic chemistry in most endothermic vertebrates. Except for thermolabile mammals (monotremes and edentates) and heterothermic endotherms any such slight change in body temperature may subject an endotherm to a serious, and potentially irreversible, physiological imbalance. When confronted with unfavorable extremes in the external thermal environment an endotherm may avoid physiological harm through behavioral and physiological means. Thus, the metabolism of endothermic vertebrates is relatively free of the effects of environmental temperatures (and other external influences) since the organism's body is maintained at a temperature lying within appropriate thermotolerant limits.

Poikilothermic vertebrate metabolism presents an altogether different set of circumstances. The term "coldblooded" implies that this type of animal is directly at the mercy of the environment (Schmidt-Nielsen, 1972), and cannot rely solely on internal regulation for accomodation to changes in environmental temperatures (Romer, 1962). Hence, the statement that "The most basic thermoregulatory 
mechanism - the behavior of seeking a suitable thermal environment - is shared by all vertebrates" (Heller, et al., in press) is much more readily applicable to poikilotherms. When a ectotherm is subjected to large differences in temperature, the animal may either adjust its internal metabolism to operate safely within conditions imposed by the environment (acclimatization), or it may seek a favorable alternate environment (behavioral thermoregulation).

Comparison of the metabolic processes of warm and cold-blooded vertebrates suggests that the common requirement of behavioral thermoregulation is more subtle than ap-parent, particularly with respect to systemic chemistry, which, in both groups of vertebrates, is a function of both respiratory and thermal input. An endotherm subjected to body temperatures outside its normal stenothermic, range, can be expected to exprience substantial shifts in plasma pH and in carbon dioxide tension (Bard, 1968; Lambertsen, 1968a, 1968b). Simple in vitro inspection of plasma $\mathrm{pH}$ and plasma $\mathrm{P}_{\mathrm{CO}_{2}}$ from such an individual would likely reveal deleterious values for these vital chemical properties (Bard, 1968; Severinghaus, 1965). If initial attempts of behavioral modification fail to maintain normal temperature levels thermal morbidity in such an individual could obviate any attempt at further protective behavioral response. On the other hand, the observed changes in blood chemistry which correspond to a concomitant change in body temperature (as 
a response to environmental change) in most air-breathing ectothermic vertebrates are generally an expression of evolutionary adaptation of tolerance to a much broader (eurythermal) set of environmental temperatures.

The fact that plasma $\mathrm{pH}$ varies inversely with temperature (Robin, 1962; Rahn, 1967; Howe11, et al., 1970) is of fundamental homeostatic importance to an ectotherm. Preservation of a constant relationship between plasma $\mathrm{pH}$ and $\mathrm{pH}$ of, neutrality of water is designed to maintain plasma $\mathrm{pH}$ slightly alkaline to neutrality by sustaining a constant ratio of $\mathrm{OH}^{-}$ions to $\mathrm{H}^{+}$ions (Rahn, 1967; Howe11, et al., 1970).

The relationship between temperature and plasma $\mathrm{pH}$ and between temperature and plasma $\mathrm{P}_{\mathrm{C}_{2}}$ in the turtle was studied by Robin.(1962) after he observed different measure- ments of acid-base metabolism in two groups of turtles of the same species from two substantially different thermal environments. Robin's work shows that an increase of body temperature results in an increased plasma $\mathrm{P}_{\mathrm{C} 0_{2}}$ and a decrease in plasma $\mathrm{pH}$. In vitro blood samples from turtles acclimated to different temperatures changed $\mathrm{pH}$ with temperature in the ratio $\Delta \mathrm{pH} / \Delta^{\circ} \mathrm{C}=-0.016$ (Robin, 1962), a value later essentially matched by Howe11, et al. (1970). In reporting results of his study Robin;also described the inverse effect of temperature on gas, solubilities and concluded that 
If the relationship between temperature and carbon dioxide tension applies not only to the turtle but generally to poikilothermic animals, it may well be that the regulation of carbon dioxide tension and $\mathrm{pH}$ within narrow limits is, from the evolutionary point of view, a temperaturedependent function (Robin, 1962).

Although Robin clearly demonstrated the occurrence of a broad pH range in turtles, he did not examine the possible operation of optimal thermal levels for maintaining systemic acid-base metabolism. The present study was undertaken to improve understanding of the relationship between thermoregulatory adaptive behavior and systemic acid-base homeostasis in North American freshwater turtles. Analysis of the behavior of differently acclimated turtles to eurythermal environmental conditions helped determine a characteristic final thermal preferendum, a value which may be functionally related to acid-base status in Pseudemys scripta elegans. 


\section{MATERIALS AND METHODS}

Twelve red-eared turtles (Pseudemys scripta elegans) were obtained from a commercial biological supply company in Louisiana. The turtles, native to that state, ranged in weight from 0.330 to $0.510 \mathrm{~kg}$. In the laboratory they were divided into two groups; each group member was identified by a distinct two-letter code (see Table I) which was permanently marked on the individual's plastron and carapace.

Group I turtles were placed in a large laboratory holding tank containing water to a depth of about $6 \mathrm{~cm}$. The water temperature varied with the ambient laboratory conditions, with an average range of $18.0-20.0^{\circ} \mathrm{C}$ maintained throughout the experimental period. This group was subjected to an artificial photoperiod with a twelve-hour light phase (between 6:45 AM and 6:45 PM PST).

Group II animals were placed in a large holding tank in an unheated roof greenhouse, thus permitting exposure to a natural photoperiod and much cooler water temperatures. Water temperatures for this group fell within the range of $7.5-11.0^{\circ} \mathrm{C}$, while air temperatures varied between 0.6 and $19.4^{\circ} \mathrm{C}$, with a mean daily temperature of $5.5^{\circ} \mathrm{C}$ (U. S. Dept. of Commerce, 1977).

Following completion of the Group I trials all Group I animals were placed in a cold tank and acclimated for two 
TABLE I

PHYSICAL CHARACTERISTICS OF EXPERIMENTAL SUBJECTS

GROUP I TURTLES $\left(18-20^{\circ} \mathrm{C}\right.$ and artificial Photoperiod acclimation)

Identification

LZ

ET

EW

. HC

AA

RF
$\underline{\operatorname{Sex}}$

M

F

F

F

M

F
Weight, $\mathrm{kg}$

0.396

0.477

0.488

0.327

0.332

0.477

GROUP II TURTLES $\left(7.5-11.0^{\circ} \mathrm{C}\right.$ and natural photoperiod acclimatization)
SP
M
0.468
DN
M
0.333
JE
M
0.384
$+\mathrm{EM}$
F
0.428
$++\mathrm{XX}$
F
0.507
FY
$\mathrm{M}$
0.362

+Expired from unknown causes shortly after completing gradient trial.

++Expired from unknown causes shortly after being placed in $10.3^{\circ} \mathrm{C}$ portion of gradient (from $9.0^{\circ} \mathrm{C}$ tank); old age suspected factor. Experimental results exclude all data regarding this subject. 
weeks at $3^{\circ} \mathrm{C} \pm 1^{\circ} \mathrm{C}$, during which time the Group II turtles were run in the gradient. The cold-acclimated Group I animals, thenceforth designated as Group III turtles, were then tested for thermal preferendum.

All acclimation tanks were pre-treated with tetracycline. The entire experiment took place during the months of February and March, 1977.

Before gradient trials began the turtles in both groups were offered food ( $r$ aw beef liver) about once every six days. Group: I turtles ate voraciously, while those individuals in Group II ate less enthusiastically.

A schematic diagram of the thermal gradient apparatus is depicted in Figure 1 . Chambers $1,2,3,4,6$, and 7 were $53 \mathrm{~cm}$ 1ong; chamber 5 was $71 \mathrm{~cm}$ long; chamber 8 was $44 \mathrm{~cm}$ long; chamber 9 was $62 \mathrm{~cm}$ long (to allow flexibility of accomodation for additional equipment in future experiments) and all chambers were $31.5 \mathrm{~cm}$ wide. Water depth was uniform at $11 \mathrm{~cm}$. The openings between the chambers were 15.5 $\mathrm{cm}$ wide.

The extreme ends of the gradient, as shown in Figure 1 show the upper and lower temperature limits, and the change of water temperature throughout the apparatus was approximately linear. The warmest temperature was maintained at about $40^{\circ} \mathrm{C}$ by controlled immersion heaters. The cold extreme in chamber 1 was kept relatively constant at $9^{\circ} \mathrm{C}$ by forcing cold tap water through stainless steel coils 


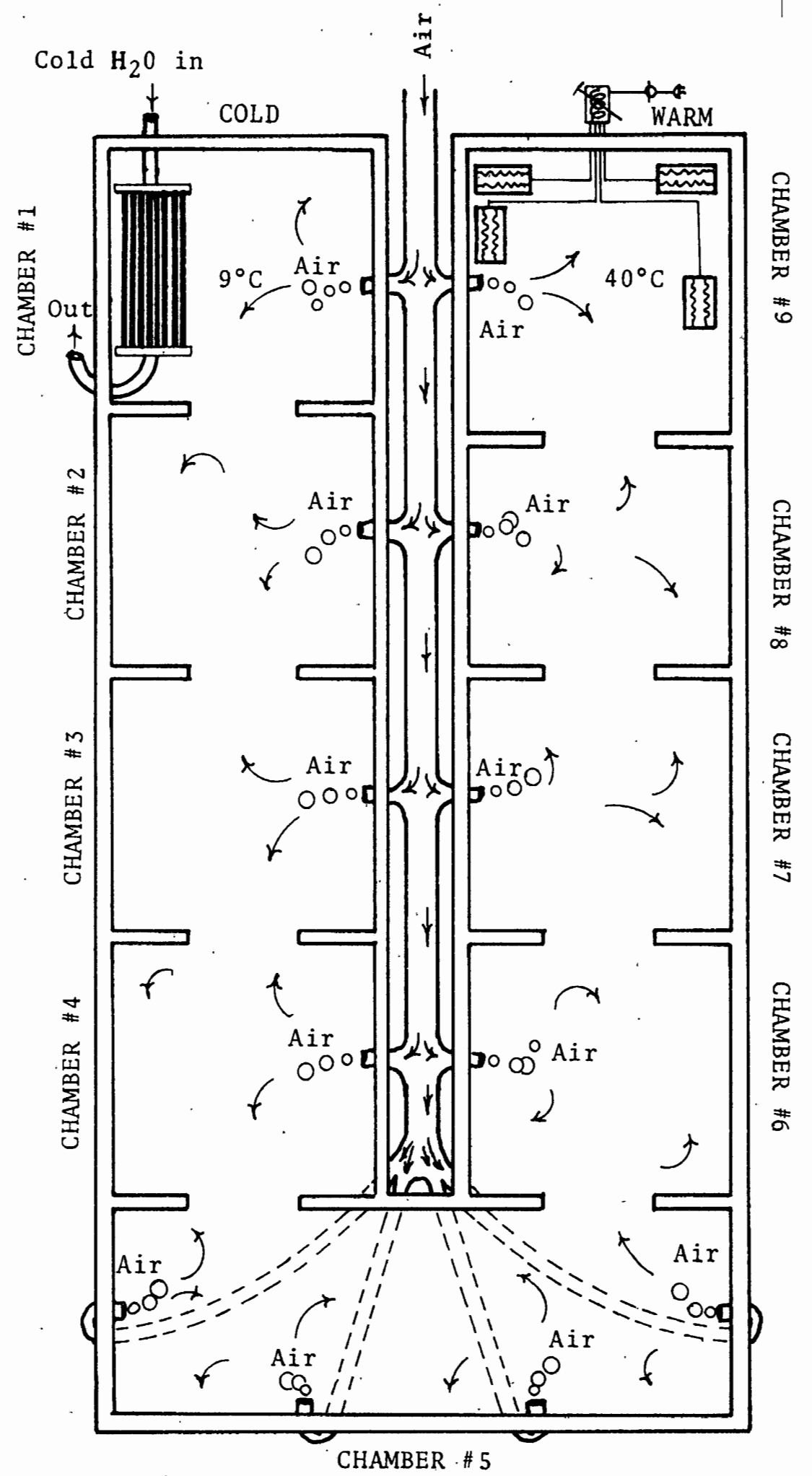

Figure 1. Temperature Gradient Apparatus 
placed in the cold end of the gradient (after Crawshaw, 1975a).

Avoidance of a vertical thermocline throughout the various gradient chambers was accomplished by vigorous bubbling of compressed air, channelled into each chamber from separate outlets of the centrally placed manifold, thereby reducing thermal stratification to about $1^{\circ} \mathrm{C}$. Thermal water convection from the end chambers produced the intermediate chamber temperatures.

The gradient was exposed to the same artificial photoperiod previously described for Group I acclimatory conditions. The gradient water was changed and treated with tetracycline weekly.

Preliminary trials were run on several individuals from Group I to visually observe which general temperatures might be preferred, and what appropriate range of temperatures should be created within the, apparatus (Laudien, 1973). Following, one week of several short orientation trials with all Group I individuals (except "LZ") these turtles were left undisturbed and unfed in the $18-20^{\circ} \mathrm{C}$ tank for four days. On the fifth day the Group I trials were begun, with "LZ" chosen as the first subject:

A copper-constantan ( $36 \mathrm{~g}$ ) thermocouple was typically attached to a turtle's carapace in the seams between the second and third central laminae, then, running posteriorly, between the left (or right) second - third lateral laminae 
and the third central lamina, finally terminating in the seam between the third and fourth central 1aminae. The thermocouple was secured with a water-resistant contact cement, and was connected to a Houston Instrument OmniScribe recorder. The recorder was calibrated to the temperatures found in the gradient, with a mercury thermometer, to $0.1^{\circ} \mathrm{C}$ accuracy. Finally, the animal was placed in the gradient chamber representative, as closely as possible, of the acclimation temperature. The turtle was then allowed free choice of the water temperature. The temperature at the dorsal neural ridge was continuously recorded and will henceforth be referred to as the "selected temperature". The trials of each group were conducted for periods of between 20 and 24 hours, each run being initiated at various times during the light phase of the photoperiod. No turtles were fed while in the gradient, nor were any Group III animals fed while undergoing acclimation in the cold tank.

Following the death of one Group II turtle in the gradient, the gradient was shut down for two days while being drained and sanitized. Great care was exercised in the cleaning and decontamination of the gradient's interior and exterior surfaces, and a tetracycline solution was spread lightly over the interior surfaces and allowed to air-dry before refilling the gradient with fresh water. The clean water was allowed to sit unheated for one day and tetra- 
cycline was added to it. Finally, the gradient heaters and coolers were turned on, and full operation resumed after allowing 12 hours for the thermal gradient to develop. 


\section{RESULTS}

Figures 2,3 and 4 depict the experimental results for individuals of each group. The continuous record of selected temperatures was integrated over 10-minute periods. Each line is a plot of the 10-minute values for the turtle indicated.

In Figure 5 each line represents the mean selected temperature for all turtles run in the designated group.

Figures 6,7 and 8 show the mean activity for each group during the 24 hours spent in the gradient. Activity numbers were obtained by assigning one activity unit for each $1.0^{\circ} \mathrm{C}$ change in selected temperature (Crawshaw, 1975a). This designation is derived from the fact that any movement within the gradient placed the turtle in water of a different temperature, therby altering the temperature at the surface of the carapace. In Figure 9 each 1 ine represents the mean thermal range within which activity took place.

An increase of activity is not necessarily an indication of change in body temperature (Crawshaw, 1975a). This is illustrated by comparing the mean selected temperatures of three groups at the arrow in Figure 5 (14 hours, 10 minutes elapsed time in gradient) with the mean thermal ranges of these groups at the same elapsed time (arrow) in Figure 9. 


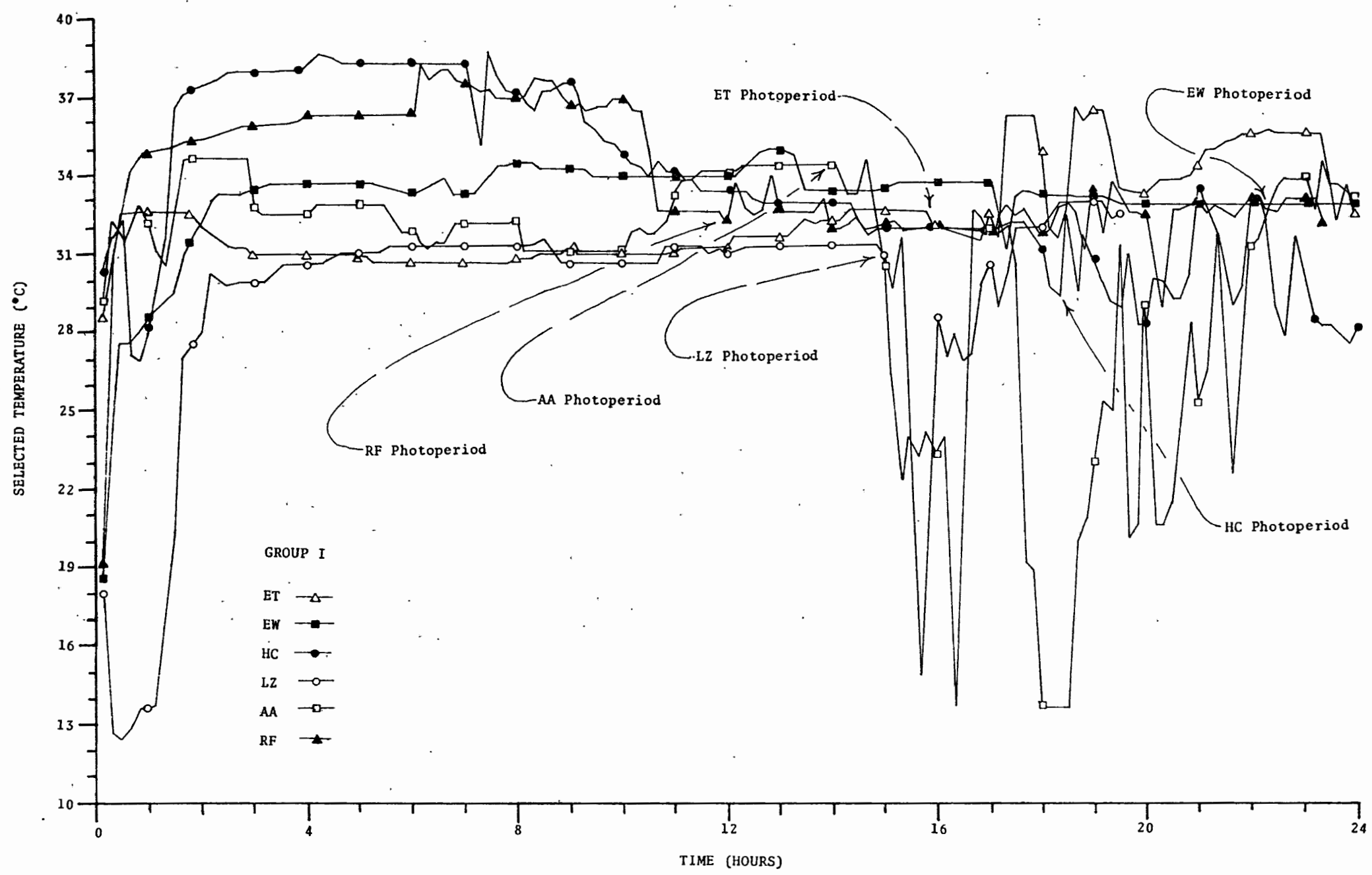

Figure 2. Selected Temperature as a function of time for the 6 turtles acclimated turtles acclimated to $18-20^{\circ} \mathrm{C}$. 


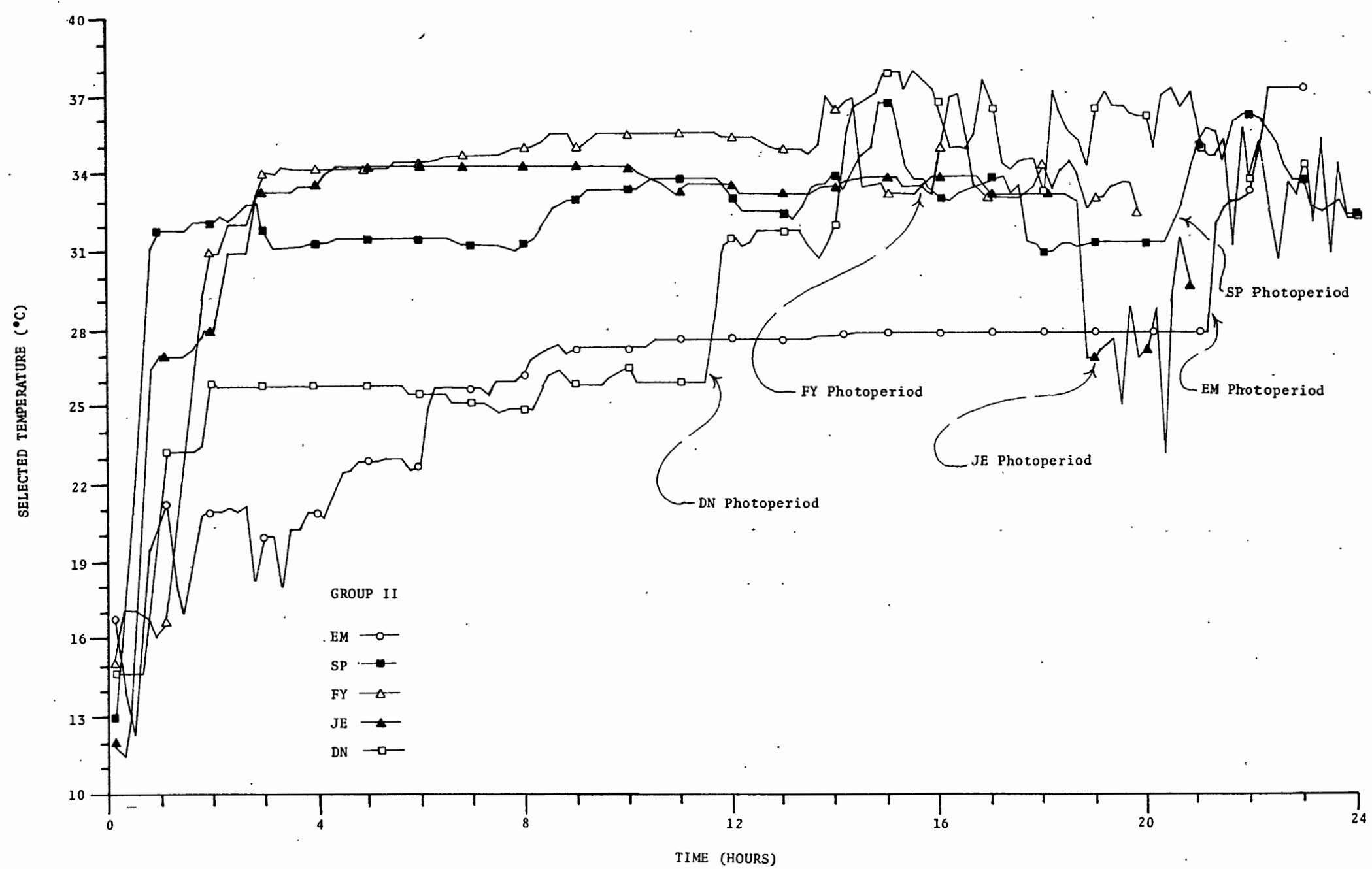

Figure 3. Selected temperature as a function of time for the 5 turtles acclimatized to natural photoperiod and 7.5-11.0 ${ }^{\circ} \mathrm{C}$. 


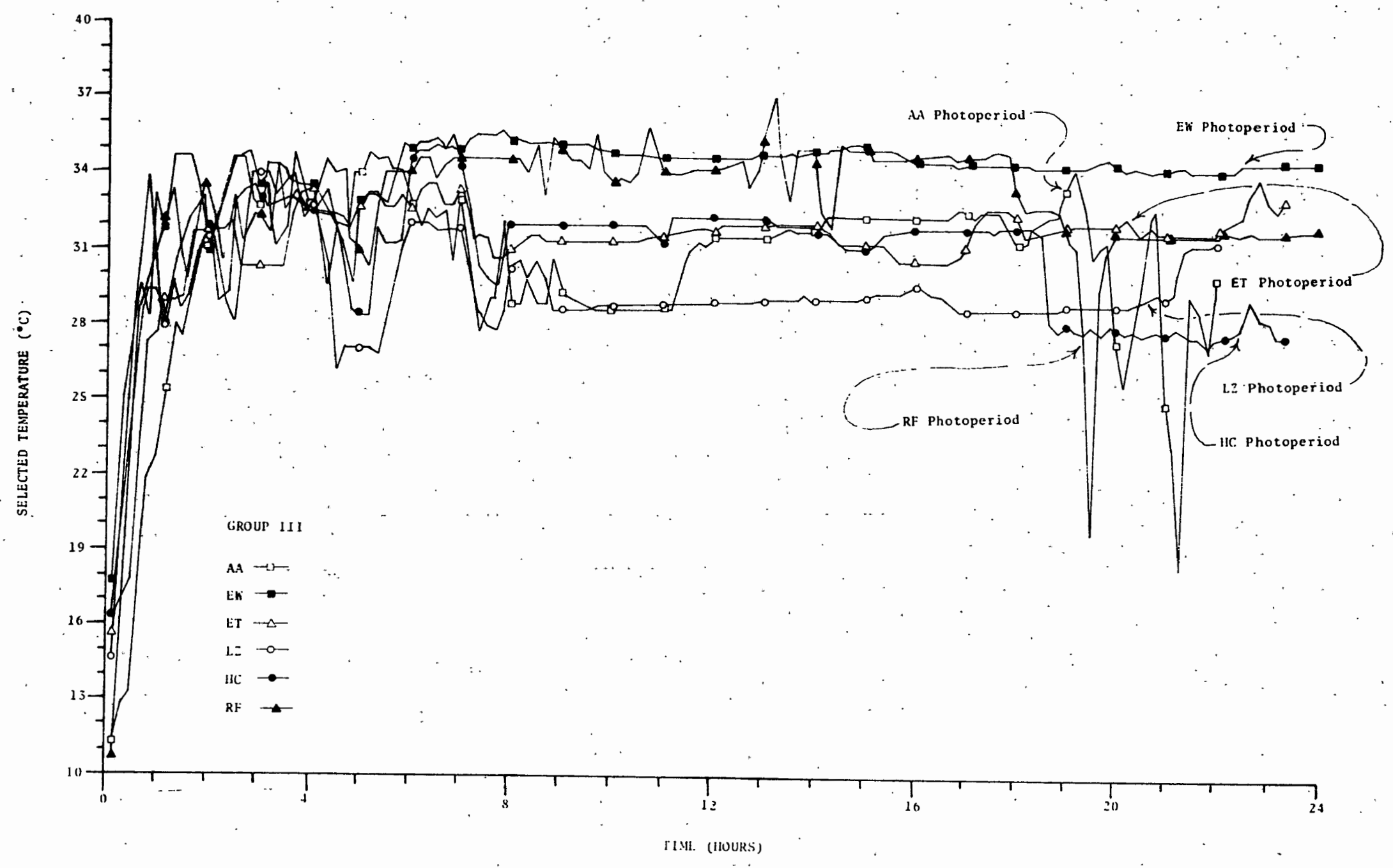

Figure 4 . selected temperature as a function of time in the o turtes acilinated to $5^{\circ}$ t. 


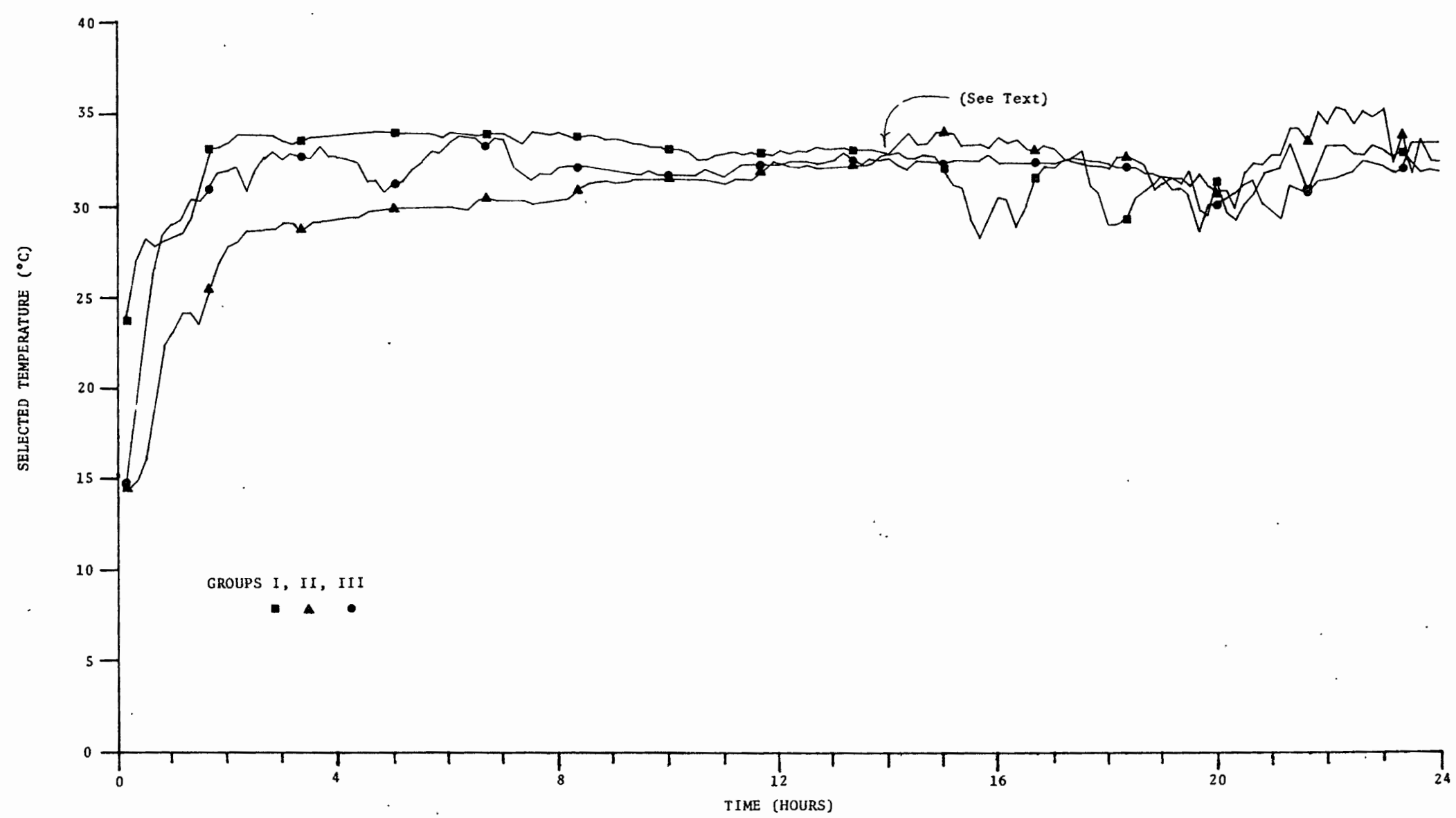

Figure 5. Mean selected temperature as a function of time for Groups I, II and III. 


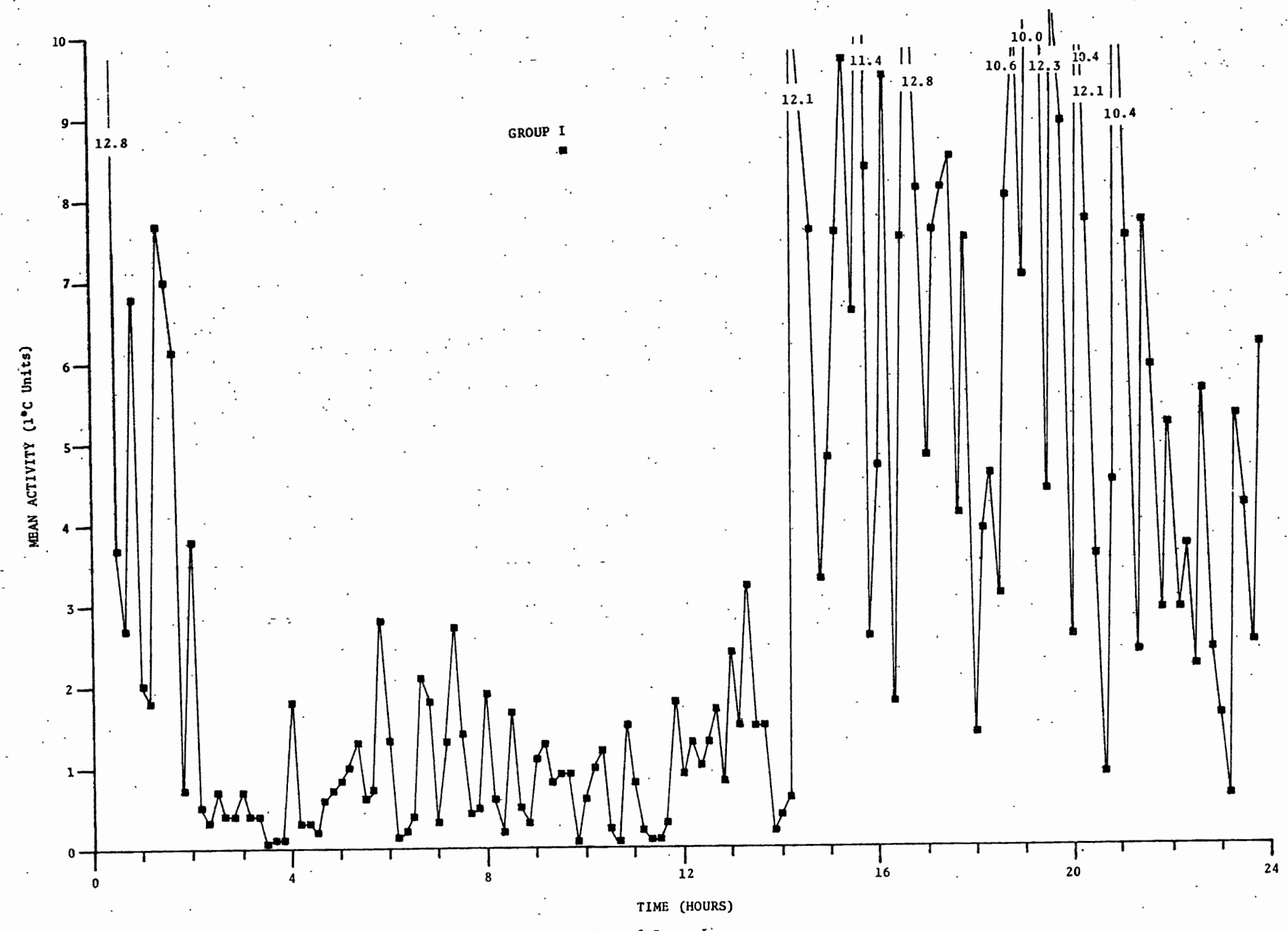

Figure 6. Mean activity as a function of. time in the 6 turtles of Group $I$ : 


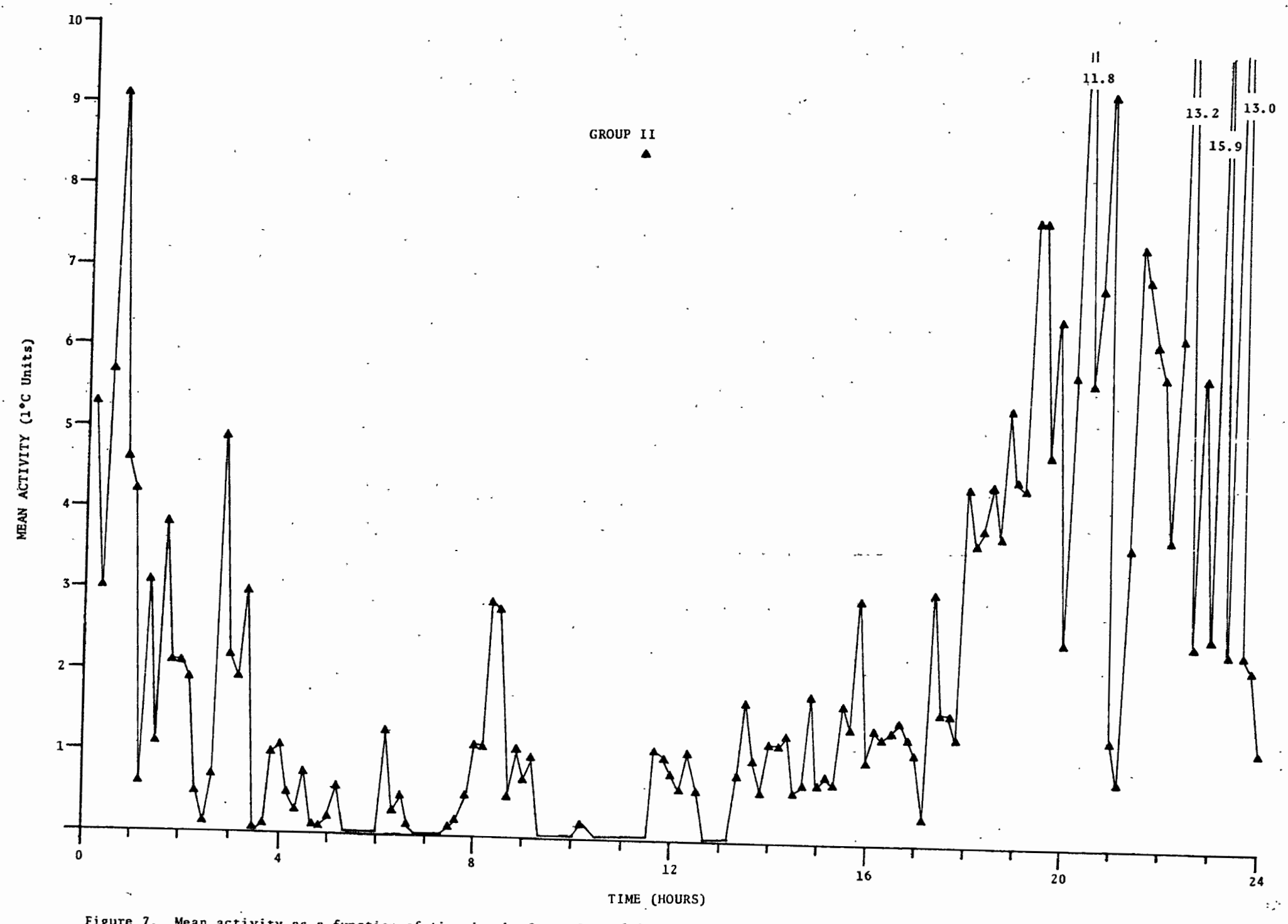

Figure 7. Mean activity as a function of time in the 5 turtles of Group II. 


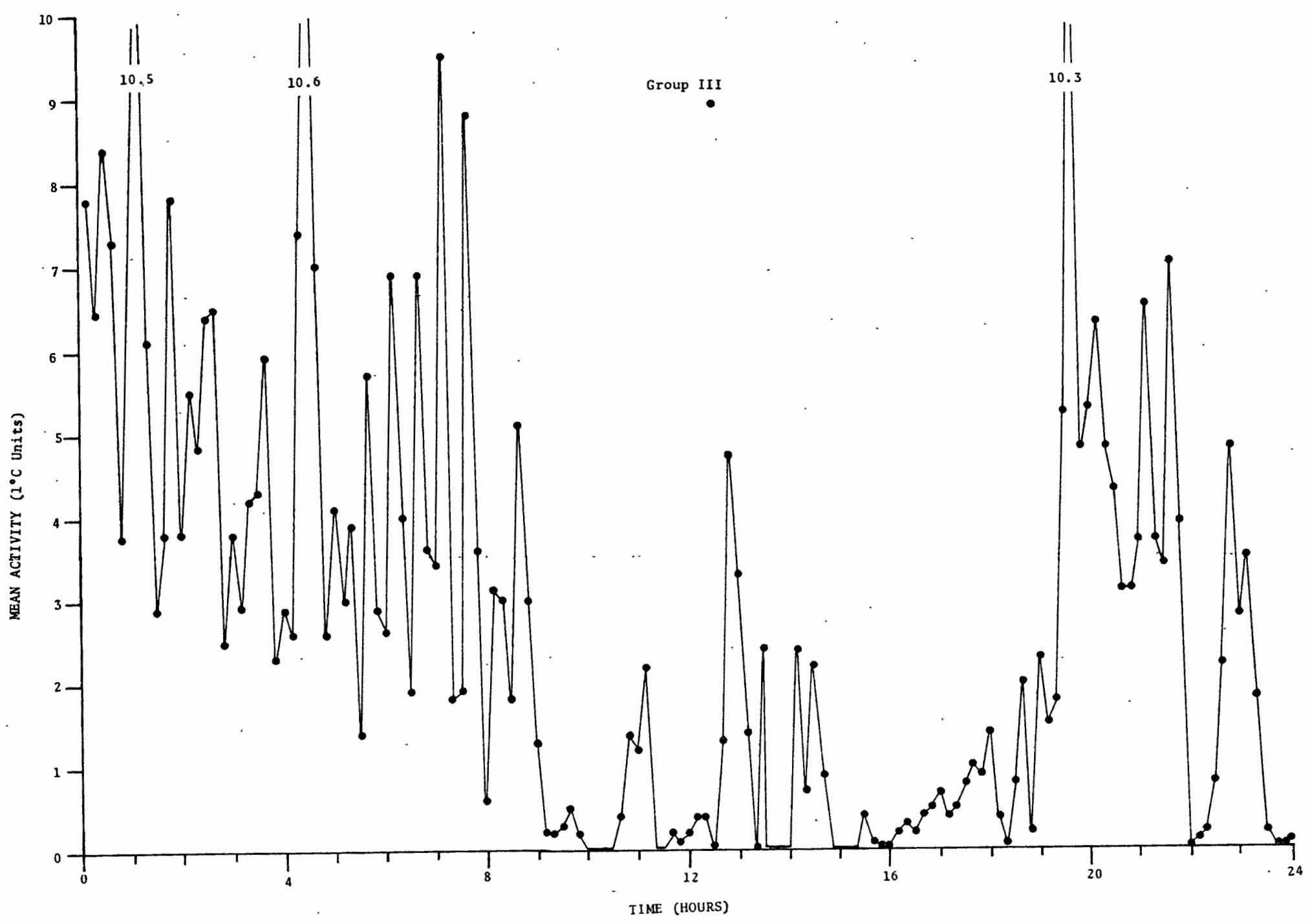

Figure 8. Mean activity as a function of time in the 6 turtles of Group III. 


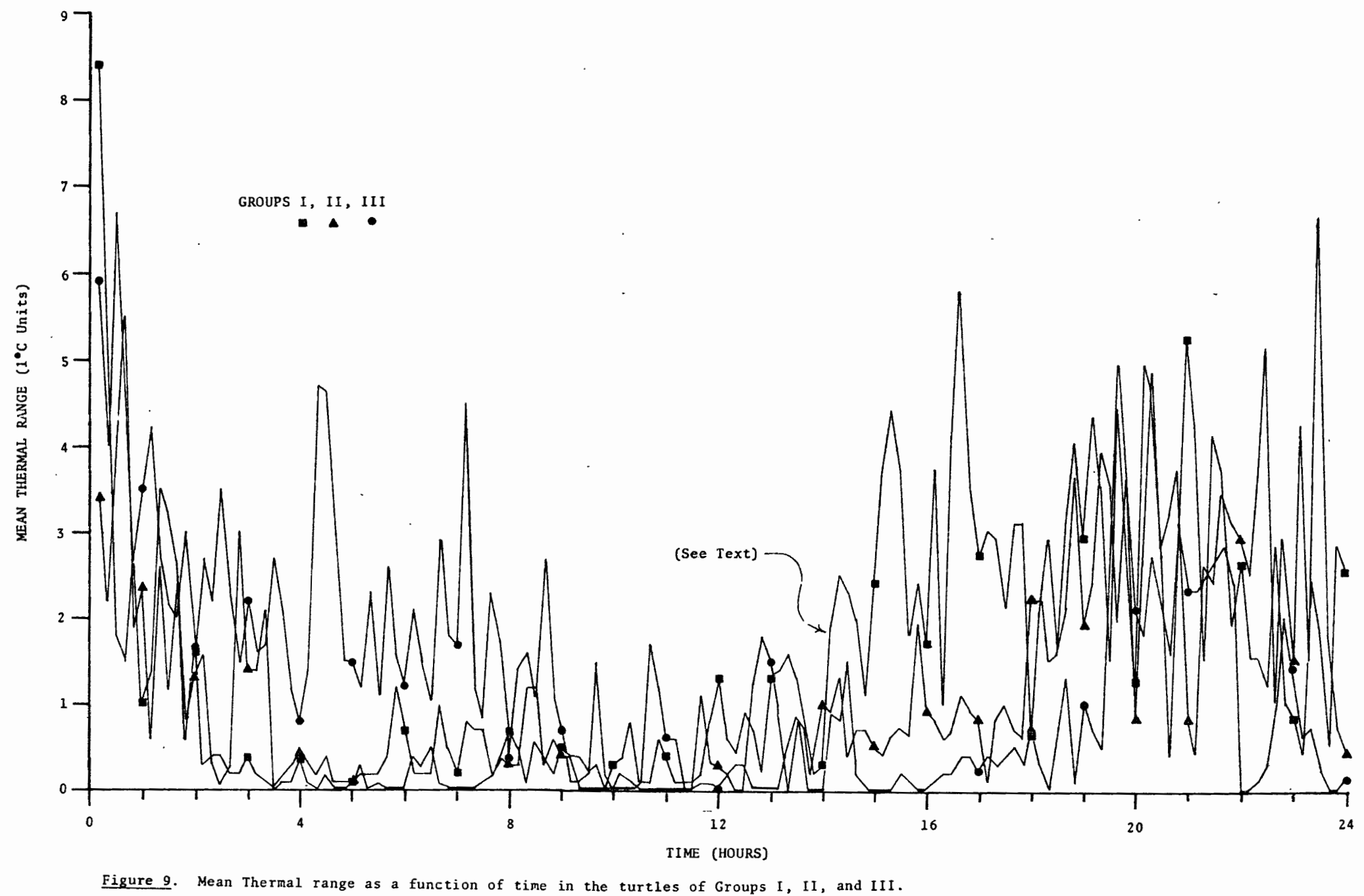


The mean selected temperatures for the complete trials of individual turtles are listed in Table II. A comparison of these values indicates that the final thermal preferendum for this species is probably between 31 and $33^{\circ} \mathrm{C}$. Comparison of mean selected temperatures (Figure 5) with mean activity in each group reveals that selection of a particular temperature in the gradient apparatus bears little relationship to overall acitivty, a proposition strengthened by the apparent independence of temperature selection and light-induced activity.

Lastly, the behavior of cold-acclimated $\left(3^{\circ} \mathrm{C}\right)$ turtles failed to show any major differences when compared with the behavior of the other groups. 
TABLE II

MEAN SELECTED TEMPERATURES OF INDIVIDUALS AND GROUPS

$$
\text { Group I Mean Selected Temp. }=32.1 \pm 1.9
$$

\begin{tabular}{cccc} 
Identification & Group & Mean Selected Temp., ${ }^{\circ} \mathrm{C}$ & $\frac{\text { Std. Dev. }}{2}$ \\
\hline LZ & I & 29.3 & 4.7 \\
ET & I & 32.6 & 1.7 \\
EW & I & 33.1 & 2.3 \\
HC & I & 33.7 & 4.0 \\
AA & I & 30.2 & 5.1 \\
RF & I & 33.9 & 2.5 \\
& Group II Mean Selected Temp. & $30.6 \pm 1.6$ & \\
SP & II & 32.1 & 2.8 \\
DN & II & 30.0 & 5.5 \\
JE & II & 32.0 & 4.0 \\
EM & II & 26.0 & 3.0 \\
FY & II & 33.1 & 2.8
\end{tabular}


TABLE II (Continued)

Group III Mean Selected Temp. $=31.3 \pm 2.4$

\begin{tabular}{cccc} 
Identification & Group & Mean Selected Temp. ${ }^{\circ} \mathrm{C}$ & Std. Dev. \\
\cline { 2 - 2 } & III & 29.4 & 1.9 \\
ET & III & 31.3 & 2.2 \\
EW & III & 34.0 & 3.0 \\
HC & III & 30.7 & 3.5 \\
AA & III & 30.3 & 3.5 \\
RF & III & 32.9 & 2.8
\end{tabular}

Probable Final Thermal Preferendum $=31-33^{\circ} \mathrm{C}$ 


\section{DISCUSSION}

\section{Acclimation}

Initial gradient response by the Group I turtles (1aboratory acclimated) was similar to that later exhibited by these same individuals after having been acclimated to $3^{\circ} \mathrm{C}$ (now experimentally designated as Group III). Further, the characteristic final selected temperature (PT) of Groups I and III was no different from the PT of Group II. The attainment of the final thermal preferendum of $31-33^{\circ} \mathrm{C}$ by Pseudemys scripta elegans, then, is very likely independent of previous thermal history. Comparable experimental results were obtained from the brown bullhead. Ictalurus nebulosus (Crawshaw, 1975b), and from the lizard Anolis carolinensis (Licht, 1968), although selection of the final thermal preferendum by bullheads was a much slower process, taking as long as 24 hours. This important difference may be explained by the fact that bullheads are water-breathers, the respiration of which is regulated by sensitivity of oxygen receptors in the respiratory control center. Airbreathers' respiratory control, on the other hand, is regulated largely by $\mathrm{CO}_{2}$ sensitivity.

Photoperiod, Activity And Thermotaxis

Analysis of various taxic responses demonstrates the 
relative thermal insignificance of gradient activity levels, a result underscored by a lack of effect of activity on the final outcome of temperature selection.

Response to initiation of the light phase in the photoperiod was clear (see Figures 2, 3 and 4), being characterized by abruptly increased activity. This uniform ${ }^{1}$ and lively response of deviation away from pre-light selected temperatures was usually followed by a rapid ${ }^{2}$ return to very nearly the same pre-light temperature. Similar relocation occurred following large thermal deviation resulting from phobic disorientation (resulting from a typical escape response after sighting human movement around the gradient).

\section{Homeostasis As A Function of Adaptive Behavior}

Thermal accuracy, here demonstrated by positive thermotaxis, has been reported in other species by Crawshaw and Hammel (1971, 1974). These investigators discussed the dependency of the control of vertebrate behavioral thermoregulatory responses on peripheral and central inputs. This followed the earlier findings of Hammel, et al (1967) ${ }^{3}$ that

\footnotetext{
${ }^{1}$ Phototaxic response was second in regularity only to selection of the final thermal preferendum.
}

${ }^{2}$ Thermal reorientation is one of the most striking features seen on the Omniscribe recordings of these trials, significance of which, it is hoped, may provoke further research.

${ }^{3}$ Cited in Heath, J. E., E. Gasdorf and R. G. Northcutt (1968 (1968). "The Effect of Thermal Stimulation of Anterior Hypothalamus on Blood Pressure in the Turtle," Comp. Biochem. Physiol. 26:509-518. 
warming (and cooling) of the preoptic hypothalamus caused an adjustment in the set points for behavioral thermoregulation. Neither study, however, investigated adjustments in acid-base status with changes in brainstem temperature. It becomes apparent, then, that these neural inputs are on1y part of an overall integrated set of thermoregulatory devices operating, in concert with other chemical and physiological mechanisms, to the best homeostatic advantage of the organism.

The effect of temperature on ventilation in $P . s$. elegans was examined by Jackson (1971). It was found that, while oxygen consumption $\left(\dot{\mathrm{V}}_{0_{2}}\right)$ increased with temperature, respiratory minute volume $\left(\hat{V}_{E}\right)$ remained independent of temperature; as a consequence the $\dot{V}_{E}$ to $\dot{V}_{0}$ ratio varied inversely with temperature, an obvious exception to the presumption that pulmonary ventilation increases in proportion to oxygen consumption. Jackson's findings indicate that homeostasis of acid-base status with respect to temperature is achieved by respiratory adjustment of arterial carbon dioxide partial pressure $\left(\mathrm{PaCO}_{2}\right)$. In pursuing this further Jackson and his colleagues.(1974) confirmed the importance of maintaining the relative alkalinity $\left(\mathrm{OH}^{-} / \mathrm{H}^{+}\right.$ ratio) proposed by Rahn (1967). They thus demonstrated the influence of temperature on ventilatory control as the mechanism responsible for the inverse relationship between blood $\mathrm{pH}$ and temperature in turtles (Jackson, et al., 1974). 
Jackson's 1971 study makes possible, through use of his experimentally-obtained oxygen extraction coefficients, the determination that the amount of consumed oxygen $\left(\hat{V}_{0_{2}}\right)$ by Pseudemys at temperatures now known to 1 ie within the turties' PT of $31-33^{\circ} \mathrm{C}$ is four times greater than at $10^{\circ} \mathrm{C}$ (Jackson, 1971). Further use of this information may be made after recalling that no ventilatory increases take place as temperature increases. The implication is that a more efficient extraction of oxygen occurs at the warmer temperatures. Efficiency seems to be further promoted by the fact that a decreased affinity of hemoglobin for oxygen at the relatively warm PT offers a consequent enhanced delivery of oxygen to the tissues, but these apparent gains are probably offset by decreased loading of $\mathrm{O}_{2}$ (SchmidtNielsen, 1975; Jackson, 1971). 


\section{CONCLUSION}

The final thermal preferendum of $31-33^{\circ} \mathrm{C}$ in Pseudemys scripta elegans is related to a variety of environmental and physiological factors. The dynamics of acid base regulation in air breathing vertebrates may underlie the rapid attainment of the final thermal preferendum seen in this study. 


\section{BIBLIOGRAPHY}

Bard, Philip. 1968. "Body Temperature Regulation" in Medical Physiology, Vol. I, ed. Vernon B. Mountcastle, 12th ed., C. V. Mosby Co., St. Louis, 553590 .

Crawshaw, L. I., and H. T. Hamme1. 1971. "Behavioral Thermoregulation in Two Species of Antarctic Fish", Life Sciences, 10:1009-1020.

Crawshaw, L. I., and H. T. Hamme1. 1974. "Behaviora1 Regulation of Internal Temperature in the Brown Bullhead, Italurus nebulosus", Comp. Biochem. Physiol., 47A:51-60.

Crawshaw, L. I. 1975a. "Twenty-four Hour Records of Body Temperature and Activity in Bluegill Sunfish (Lepomis macrochirus) and Brown Bullheads (Ictalurus nebulosus)", Comp. Biochem. Physiol., 51A:11-14.

Crawshaw, L. I. 1975b. "Attainment of the Final Thermal Preferendum in Brown Bullheads Acclimated to Different Temperatures", Comp. Biochem. Physiol., 52A: $171-173$.

Hamme1, H. T., F. T. Caldwell and R. M. Abrams. 1967. "Regulation of Body Temperature in the BlueTongued Lizard", Science, 156:1260-1262.

Heath, J. E., E. Gasdorf and R. G. Northcutt (cited). (1968). "The Effect of Thermal Stimulation of Anterior Hypothalamus on Blood Pressure in the Turtle", Comp. Biochem. Physiol. 26:509-518.

Heller, Craig H., Larry I. Crawshaw and Harold T. Hamme1. In Press. "The Vertebrate Thermostat", Scientific American.

Howe11, B. J., F. W. Baumgardner, K. Bondi and H. Rahn. 1970. "Acid-Base Balance in Cold-Blooded Vertebrates as a Function of Body Temperature", Am. J. Physiol., 218:600-606.

Jackson, Donald C. 1971. "The Effect of Temperature on Ventilation in the Turtle, Pseudemys scripta elegans", Resp. Physiol., 12:131-140. 
Jackson, Donald C., Scott E. Palmer and William L. Meadow. 1974. "The Effects of Temperature and Carbon Dioxide Breathing on Ventilation and AcidBase Status of Turtles", Resp. Physiol., 20:13131346 .

Lambertsen, Christian J. 1968a. "Transport of Oxygen and Carbon Dioxide by the Blood", in Medical Physiology, Vo1. I, ed. Vernon B. Mountcastie, 12th ed., C. V. Mosby Co., St. Louis. 660-686.

Lambertsen, Christian J. 1968b. "Interactions of Physical, Chemical, and Nervous factors in Respiratory Contro1", in Medical Physiology, Vo1. I., ed. Vernon B. Mountcast1e, 12th ed., C. V. Mosby Co., St. Louis. 764-791.

Laudien, H. 1973. "Orientation in Temperature-Stimulus Fields with Gradients", in Temperature and Life, by Precht, H., J. Christophersen, H. Hensel, and W. Larcher, Springer-Verlag, Berlin. 458-465.

Licht, Paul. 1965. "Effects of Temperature on Heart Rates of Lizards During Rest and Activity", Physio1. Zool., 38:129-137.

Licht, Paul. 1968. "Response of the Thermal Preferendum and Heat Resistance to Thermal Acclimation Under Different. Photoperiods in the Lizard Anolis carolinensis", Amer. Midland Naturalist, 79:149-158.

Rahn, H. 1967. "Gas Transport from the External Environment to the Cells", in Development of the Lung, Ciba Foundation Symposium, ed. A. V. S. deReuck and R. Porter. Little, Brown Publishing Co., Boston, 3-23.

Robin, Eugene D. 1962. "Relationship Between Temperature and Plasma $\mathrm{pH}$ and Carbon Dioxide Tension in the Turtle", Nature, 195:249-251.

Romer, Alfred Sherwood. 1962. The Vertebrate Body, 3rd ed., W., B. Saunders Co., Philadelphia. p. 143.

Schmidt-Nielsen, Knut. 1972. How Animals Work, Cambridge University Press, London, p. 2 .

Schmidt-Nie1sen, Knut. 1975. Animal Physiology-Adaptation and Environment, Cambridge University Press, London. 
Severinghaus, John W. 1965. "Blood Gas Concentrations", in Handbook of Physiology, ed. W. O. Fenn and H. Rahn, American Physiological Society, Washington, D. C., ch. 61 .

U. S. Department of Commerce. 1977. National Oceanic and Atmospheric Administration, National Weather Service, Portland, Oregon. 